\title{
Isolasi dan Identifikasi Bakteri Tanah di Hutan Sekitar Danau Kalimpa'a, Kawasan Taman Nasional Lore Lindu, Sulawesi Tengah
}

\author{
Isolation and Identification of Soil Bacteria in Forest Around \\ Lake Kalimpa'a, Lore Lindu National Park Area, Central Sulawesi
}

Orryani Lambui* dan Magfirahtul Jannah

Lab. Bioteknologi, Jurusan Biologi, Fakultas MIPA, Universitas Tadulako, Palu 94118

\begin{abstract}
Lore Lindu National Park in Central Sulawesi has high litter productivity, so it relies on the presence of soil microorganisms in decomposing it into nutrients used by plants. Primary forest conditions that still natural can support the growth and diversity of soil microorganisms, mainly bacteria. This study aims to identify the types of soil bacteria in the forest around the Lake Kalimpa'a in Lore Lindu National Park area. This research was conducted from October to December 2016 at the Laboratory of Biotechnology Department of Biology, Faculty of Basic Science Tadulako University. Bacteria were isolated from the rhizosphere soil samples taken at random in a few small areas, using enrichment and spread plate method to obtain isolates. The isolate was then purified by streak plate method then identified based on microbiological and biochemical tests. From samples of land forest around Lake Kalimpa'a was isolated 5 selected bacterial isolates with isolates code of DKL 1, DKL 2, DKL 3, DKL 4 and DKL 5. Based on the phenotypic identification, selected isolates were a member of Gram-negative bacterias with cell shape coccus and bacil, there were motile and non-motile, and capable of using carbohydrates as a source of energy through a fermentation process.
\end{abstract} Park.

Keywords: $\quad$ Isolation, Identification, Soil Bacteria, Forest, Lore Lindu National ABSTRAK
Taman Nasional Lore Lindu Sulawesi Tengah memiliki produktivitas serasah yang
tinggi, sehingga sangat bergantung pada keberadaan mikroorganisme tanah untuk
mendekomposisinya menjadi unsur hara yang dimanfaatkan oleh tumbuhan. Kondisi hutan
primer yang masih alami dapat mendukung pertumbuhan dan keanekaragaman
mikroorganisme tanah terutama bakteri. Penelitian ini bertujuan untuk mengidentifikasi jenis-
jenis bakteri tanah di hutan sekitar Danau Kalimpa'a kawasan Taman Nasional Lore Lindu.
Penelitian ini dilakukan pada bulan Oktober sampai Desember 2016 di Laboratorium
Bioteknologi Jurusan Biologi FMIPA Universitas Tadulako. Bakteri diisolasi dari sampel
tanah rizosfir yang diambil secara random di beberapa area kecil, menggunakan metode
enrichment dan spread plate untuk memperoleh isolat. Isolat dimurnikan dengan metode
streak plate kemudian diindentifikasi berdasarkan uji mikrobiologis dan uji biokimiawi. Dari
sampel tanah hutan di sekitar Danau Kalimpa'a Kawasan Taman Nasional Lore Lindu
berhasil diisolasi 5 bakteri isolat terpilih dengan kode isolat DKL 1, DKL 2, DKL 3, DKL 4 
dan DKL 5. Berdasarkan hasil identifikasi secara fenotipik, isolat terpilih merupakan anggota kelompok bakteri Gram negatif dengan bentuk sel coccus dan bacil, ada yang bersifat motil dan non motil, serta mampu menggunakan karbohidrat sebagai sumber energinya melalui proses fermentasi.

Kata Kunci: Isolasi, Identifikasi, Bakteri Tanah, Hutan, Taman Nasional Lore Lindu.

\section{LATAR BELAKANG}

Taman Nasional Lore Lindu (TNLL) merupakan salah satu Taman Nasional di Sulawesi. Berdasarkan Surat Keputusan Direktur Jenderal Perlindungan Hutan dan Konservasi Alam No SK 105/IVKKBHL/2015, TNLL terletak di wilayah Kabupaten Sigi dan Poso Provinsi Sulawesi Tengah, dengan kawasan seluas 215.733,70 ha (BBTNLL, 2015). Sebanyak 90\% kawasan TNLL didominasi oleh hutan pegunungan (1.000-2.500 $\mathrm{m} \quad \mathrm{dpl})$, sedangkan sisanya merupakan hutan dataran rendah (200-1.000 $\mathrm{m} \mathrm{dpl)} \mathrm{(TNC,}$ 2001; Pitopang, 2006).

Keanekaragaman hayati yang tinggi di kawasan TNLL meningkatkan produktivitas serasah tanaman yang dibuang di tanah. Semua produk buangan tersebut pada akhirnya akan diuraikan oleh mikroorganisme tanah dan dapat dimanfaatkan kembali oleh tumbuhan. Proses penguraian produk buangan yang mengandung bahan organik yang kompleks menjadi bahan anorganik yang sederhana hanya mampu dilakukan oleh mikroorganisme tanah seperti bakteri (Simanungkalit, 2006).
Kelompok bakteri tanah hidup pada lapisan rizosfir. Pada hutan alami, bakteri yang paling terkenal adalah rizobakteri yang merupakan pemicu tumbuh tanaman atau plant growth promoting rhizobacteria (PGPR) (Kloepper et al., 1991; Glick, 1995). Menurut Kloepper (1993), beberapa jenis bakteri dari kelompok bakteri PGPR telah berhasil diidentifikasi. Sebagian besar jenis bakteri yang ditemukan adalah dari genus Pseudomonas dan beberapa jenis genus Seratia. Glick (1995) juga melaporkan ditemukan jenis bakteri dari genus Azotobacter, Azospirillum, Acetobacter, Burkholderia dan Bacillus.

Danau Kalimpa'a termasuk dalam kawasan TNLL, terletak di Desa Sedoa Kecamatan Lore Utara Kabupaten Poso. Danau Kalimpa'a terletak pada ketinggian $1.700 \mathrm{~m}$ dpl dengan hutan pegunungan yang masih alami. Kondisi hutan primer di sekitar Danau Kalimpa'a dapat mendukung pertumbuhan dan keanekaragaman mikroorganisme tanah terutama bakteri. Hingga saat ini, data keanekaragaman jenis-jenis bakteri tanah di kawasan TNLL belum tersedia. Penelitian ini bertujuan untuk mengidentifikasi jenis-jenis bakteri 
tanah yang terdapat pada hutan di sekitar Danau Kalimpa'a kawasan TNLL. Hasil penelitian ini diharapkan dapat menambah database keanekaragaman hayati Sulawesi Tengah dan informasi tersebut dapat dimanfaatkan oleh peneliti dan stake holder dalam pengelolaan sumber daya hayati secara berkelanjutan.

\section{BAHAN DAN METODE}

\section{Sterilisasi Alat dan Medium}

Seluruh alat gelas yang digunakan dibungkus dengan kertas, lalu disterilisasi menggunakan oven pada suhu $170-180^{\circ} \mathrm{C}$ selama 2-3 jam dan menggunakan autoklaf pada suhu $121^{\circ} \mathrm{C}$ dengan tekanan 2 atm selama 15 menit. Medium Nutrient Agar (NA), Nutrient Broth (NB) dan Lactosa Broth (LB) ditakar sesuai kebutuhan, kemudian dipanaskan sampai larut. Medium disterilisasi menggunakan autoklaf pada suhu $121^{\circ} \mathrm{C}$ dengan tekanan 2 atm selama 15 menit (Cappuccino and Sherman, 2008).

\section{Pengambilan Sampel}

Pengambilan sampel tanah dilakukan secara random di beberapa area kecil. Permukaan tanah dibersihkan kemudian dilakukan pengukuran $\mathrm{pH}$ dan kelembaban tanah menggunakan soil tester. Sampel tanah diambil pada bagian tanah rizosfir dengan kedalaman $5 \mathrm{~cm}$ menggunakan bor tanah. Sampel tanah dimasukkan ke dalam wadah pastik steril, diaduk menggunakan spatula dan disimpan dalam kotak es (Saraswati $d k k$, 2007). Seluruh proses pengambilan sampel dilakukan dalam keadaan steril.

\section{Isolasi Bakteri Tanah}

Isolasi bakteri tanah dilakukan dengan metode enrichment (Lambui $d k k$, 2015) dan spread plate. Sebanyak $10 \mathrm{~g}$ sampel tanah dimasukkan ke dalam $90 \mathrm{ml}$ medium NB, kemudian diinkubasi 1-2 hari pada suhu $37^{\circ} \mathrm{C}$, dilanjutkan dengan pengenceran menggunakan $\mathrm{NaCl}$ fisiologis $0,8 \%$ hingga $10^{-12}$. Masing-masing pengenceran $10^{-8}-10^{-12}$ diambil $0,1 \mathrm{ml}$ untuk disurface spread plate pada medium NA dan diinkubasi pada suhu $37^{\circ} \mathrm{C}$ selama 1-2 hari. Koloni bakteri yang tumbuh terpisah selanjutnya dimurnikan menggunakan metode streak plate pada medium NA. Isolat murni kemudian diidentifikasi berdasarkan karakteristik yang mengacu pada Bergey's Manual of Determinative of Microorganism (Sneath et al., 1986).

\section{Identifikasi Isolat Terpilih}

Identifikasi secara fenotipik dilakukan dalam 2 tahapan, yaitu uji mikrobiologis dan uji biokimiawi.

1. Uji mikrobiologis meliputi pengamatan morfologi secara makroskopis dan mikroskopis. Pengamatan makroskopis dilakukan dengan mengamati secara langsung ciri-ciri koloni bakteri isolat 
menggunakan colony counter, meliputi: ukuran, warna, bentuk, margin, dan elevasi koloni (Lay, 1994).

Pengamatan mikroskopis dilakukan dengan mengamati bentuk sel bakteri yang telah diwarnai melalui pengecatan Gram dan uji motilitas.

a. Pengecatan Gram dilakukan berdasarkan cara kerja Joetono $d k k$ (1980). Sebanyak 1 ose suspensi bakteri diletakkan pada gelas benda dan difiksasi di atas api. Selanjutnya secara berturut-turut diberikan larutan kristal violet (Gram A) selamat 1 menit, larutan Mordan (Gram B) 1 menit, larutan aseton-alkohol (Gram C) 30 menit, dan larutan Safranin (Gram D) 2 menit. Pengamatan dilakukan di bawah mikroskop, dimana bakteri Gram positif berwarna ungu, sedangkan Gram negatif berwarna merah.

b. Uji motilitas dilakukan mengikuti cara kerja Rahayu dan Margino (1997). Sebanyak $2 \mathrm{ml}$ medium NA (konsentrasi agar 0,5\%) dimasukkan dalam tabung reaksi dan dipadatkan. Selanjutnya bakteri isolat diinokulasi dengan cara tusukan tegak pada medium NA dan diinkubasi selama 24 jam. Bakteri bersifat motil jika pertumbuhannya menyebar ke seluruh media, tidak hanya pada daerah tusukan.

2. Uji biokimiawi meliputi uji pembentukan gas dari fermentasi karbohidrat, yang dilakukan berdasarkan metode kerja Trimulyono (2010). Isolat yang diperoleh diinkubasi selama 24 jam pada medium LB berisi tabung durham yang dipasang terbalik. Satu tabung tanpa sumber karbon diinokulasi dengan $1 \mathrm{ml}$ kultur yang telah diinkubasi selama 24 jam. Inkubasi dilakukan pada suhu $30^{\circ} \mathrm{C}$ selama 1,3 atau 5 hari tergantung dari tumbuhnya kultur. Terbentuknya gas terjadi bila terdapat gelembung gas pada tabung durham.

\section{Pembuatan Stok Bakteri Isolat}

Kultur murni yang berhasil diisolasi kemudian disimpan pada NA miring dengan $20 \%$ gliserol pada suhu $4^{\circ} \mathrm{C}$ sebagai koleksi bakteri isolat (Aanniz et al., 2015).

\section{Analisa Data}

Data isolasi, karakterisasi dan identifikasi bakteri isolat dianalisis secara deskriptif.

\section{HASIL DAN PEMBAHASAN}

\section{Isolasi Bakteri Tanah}

Isolasi bakteri dari sampel tanah yang berasal dari hutan primer sekitar Danau Kalimpa'a kawasan TNLL Sulawesi Tengah ditandai dengan terbentuknya koloni yang melimpah (Gambar 1). Setelah 
melalui tahap pemurnian diperoleh 5 koloni bakteri isolat terpilih.

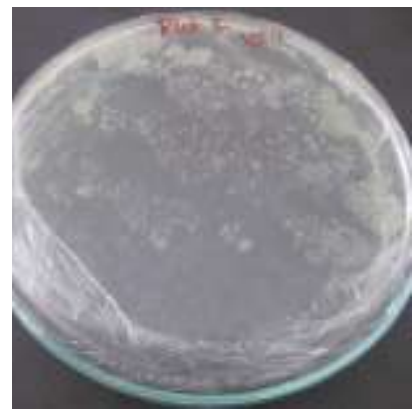

Gambar 1. Koloni bakteri sampel tanah pada medium NA

Tahapan isolasi merupakan tahapan terpenting, diawali dengan perlakuan enrichment menggunakan medium NB untuk mensuplai ketersediaan nutrisi bagi pertumbuhan mikroorganisme tanah. Perlakuan kemudian dilanjutkan dengan menumbuhkan bakteri pada medium NA secara surface spread plate. Setiap koloni yang tumbuh pada medium NA dipilih yang mempunyai bentuk koloni tunggal dan diberi kode isolat DKL. Isolat terpilih diinokulasikan kembali ke medium NA dalam cawan petri untuk dilakukan pemurnian dengan metode streak quadrant. Koloni tunggal yang tumbuh kemudian dipindahkan ke medium NA miring.

Pengamatan secara makroskopis pada medium NA menunjukkan bahwa ciri morfologi koloni bakteri isolat berbentuk sirkulair, berwarna putih, dengan margin (tepian) berbentuk lobate dan elevasi koloni berbentuk convex. Hal ini menunjukkan bahwa koloni isolat dapat tumbuh baik pada medium. Hasil pengamatan morfologi koloni isolat disajikan pada Tabel 1.

Tabel 1. Morfologi koloni bakteri isolat terpilih

\begin{tabular}{|c|c|c|c|c|c|}
\hline \multirow{2}{*}{ No } & \multirow{2}{*}{$\begin{array}{l}\text { Isolat } \\
\text { terpilih }\end{array}$} & \multicolumn{4}{|c|}{ Morfologi Koloni } \\
\hline & & Warna & Bentuk & Margin & Elevasi \\
\hline 1 & DKL 1 & $\begin{array}{l}\text { Putih } \\
\text { susu }\end{array}$ & Sirkulair & Lobate & Convex \\
\hline 2 & DKL 2 & Putih & Sirkulair & Lobate & Convex \\
\hline 3 & DKL 3 & $\begin{array}{l}\text { Putih } \\
\text { susu }\end{array}$ & Sirkulair & Lobate & Convex \\
\hline 4 & DKL 4 & Putih & Sirkulair & Lobate & Convex \\
\hline 5 & DKL 5 & Putih & Sirkulair & Lobate & Convex \\
\hline
\end{tabular}

Berdasarkan Tabel 1, kelima isolat terpilih memiliki morfologi koloni yang hampir sama. Khusus untuk isolat DKL 1 dan DKL 3 memiliki warna koloni putih susu, sedangkan isolat DKL 2, DKL 4 dan DKL 5 memiliki warna koloni putih. Untuk bentuk koloni, margin dan elevasi kelima isolat terpilih memiliki bentuk yang sama yaitu sirkulair, lobate dan convex.

Dwijoseputro (2005) mengatakan bahwa koloni bakteri memiliki sifat-sifat khusus dalam medium padat, dimana bentuk koloni dapat digambarkan sebagai titik, bulat atau sirkulair, filamentus dan tak teratur. Permukaan koloni dapat rata, timbul rata, melengkung, mencembung, membukit dan serupa kawah, sedangkan tepian koloni dapat berbentuk utuh atau entire, berbelah atau lobate, berbenang atau filamentus dan keriting (curled). Pada warna, koloni bakteri sebagian besar berwarna keputihan atau kekuningan. 


\section{Identifikasi Bakteri Isolat Terpilih}

Kelima bakteri isolat terpilih diidentifikasi secara mikroskopis melalui pengecatan Gram. Hasil pengecatan Gram kelima isolat menunjukkan bahwa semua isolat adalah anggota kelompok bakteri Gram negatif (Tabel 2), ditandai dengan sel bakteri berwarna merah. Bentuk dan susunan sel bakteri didominasi bakteri berbentuk coccus (bulat) berpasangan atau berantai, khususnya pada isolat DKL 1, DKL 2, DKL 3 dan DKL 5, sedangkan isolat DKL 4 berbentuk bacil (batang).

Menurut Pelczar and Chan (1986), mekanisme pewarnaan Gram didasarkan pada struktur dan komposisi dinding sel bakteri. Bakteri Gram negatif memiliki dinding sel yang cukup tipis dan komposisi lipid yang cukup tinggi yaitu 11-22\%, sedangkan bakteri Gram positif memiliki dinding sel yang cukup tebal dan hanya memiliki kandungan lipid sebesar 1-4\%. Selain itu, kandungan peptidoglikan pada dinding sel bakteri Gram negatif lebih sedikit dibandingkan kandungan peptidoglikan pada dinding sel bakteri Gram positif.

Berdasarkan uji motilitas diperoleh isolat DKL 3 bersifat motil, ditandai dengan adanya pertumbuhan pada daerah di sekitar tusukkan isolat (Gambar 2). Hal ini berarti bahwa isolat DKL 3 memiliki flagela. Keempat isolat lainnya (DKL 1,
DKL 2, DKL 4 dan DKL 5) bersifat nonmotil.

Pada uji biokimiawi melalui pembentukan gas dari fermentasi karbohidrat, diperoleh hasil bahwa semua isolat bakteri terpilih dapat menghasilkan gelembung gas. Hal ini dibuktikan dengan adanya gelembung gas yang terperangkap dalam tabung durham yang dipasang terbalik pada tabung reaksi berisi medium LB (Gambar 3).

Fermentasi adalah proses penggunaan senyawa makromolekul organik menjadi senyawa sederhana oleh aktivitas mikroorganisme pada kondisi anaerob. Pada penelitian ini, tampak isolat terpilih memanfaatkan subsrat laktosa sebagai sumber energinya melalui proses fermentasi, yang ditandai dengan terperangkapnya gelembung gas pada tabung durham. Menurut McNeil and Harvey (2008), mikroorganisme yang berbeda akan menggunakan karbohidrat yang berbeda tergantung dari komponen enzim yang dimilikinya.

Berdasarkan penelitian yang telah dilakukan, bakteri tanah berhasil diisolasi dari sampel tanah hutan di sekitar Danau Kalimpa'a kawasan TNLL dan diperoleh 5 isolat terpilih dengan kode isolat DKL 1, DKL 2, DKL 3, DKL 4 dan DKL 5. Berdasarkan hasil identifikasi secara fenotipik, isolat terpilih merupakan anggota 
kelompok bakteri Gram negatif dengan bentuk sel coccus dan bacil, ada yang bersifat motil dan non motil, serta mampu menggunakan laktosa sebagai sumber energinya melalui proses fermentasi. Kedepannya perlu dilakukan penelitian lebih lanjut terhadap identifikasi isolat terpilih baik itu secara fenotipik maupun molekular, sehingga dapat diketahui jenisjenis bakteri tanah pada hutan di sekitar Danau Kalimpa'a kawasan TNLL Sulawesi Tengah.

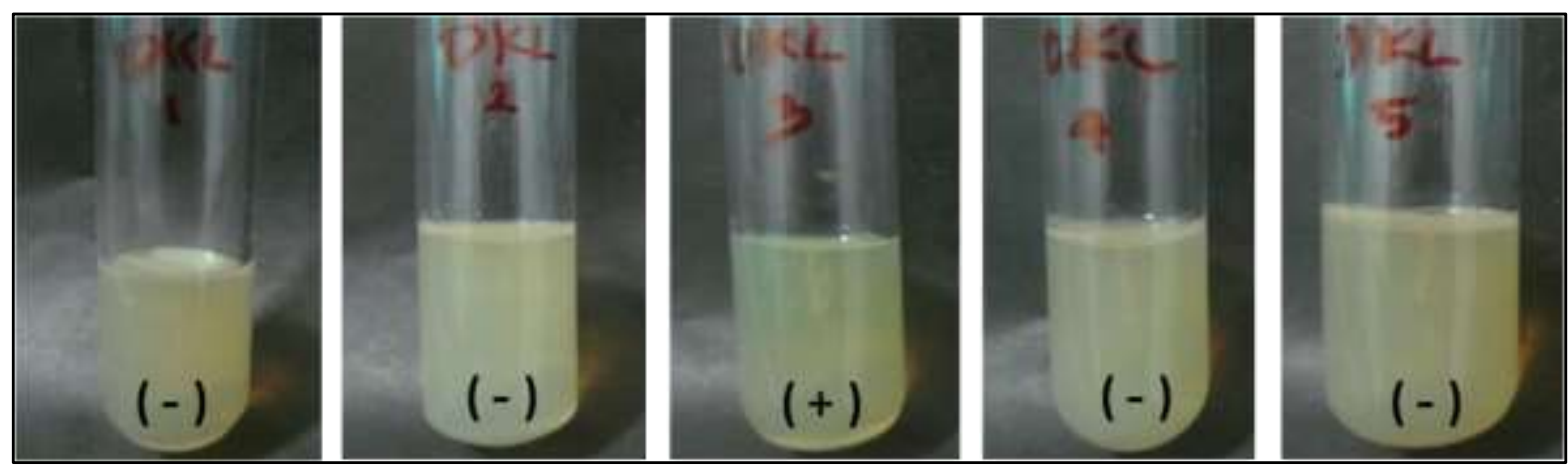

Gambar 2. Hasil uji motilitas bakteri isolat DKL 1-5 (dari kiri ke kanan): (-) tes negatif; (+) tes positif

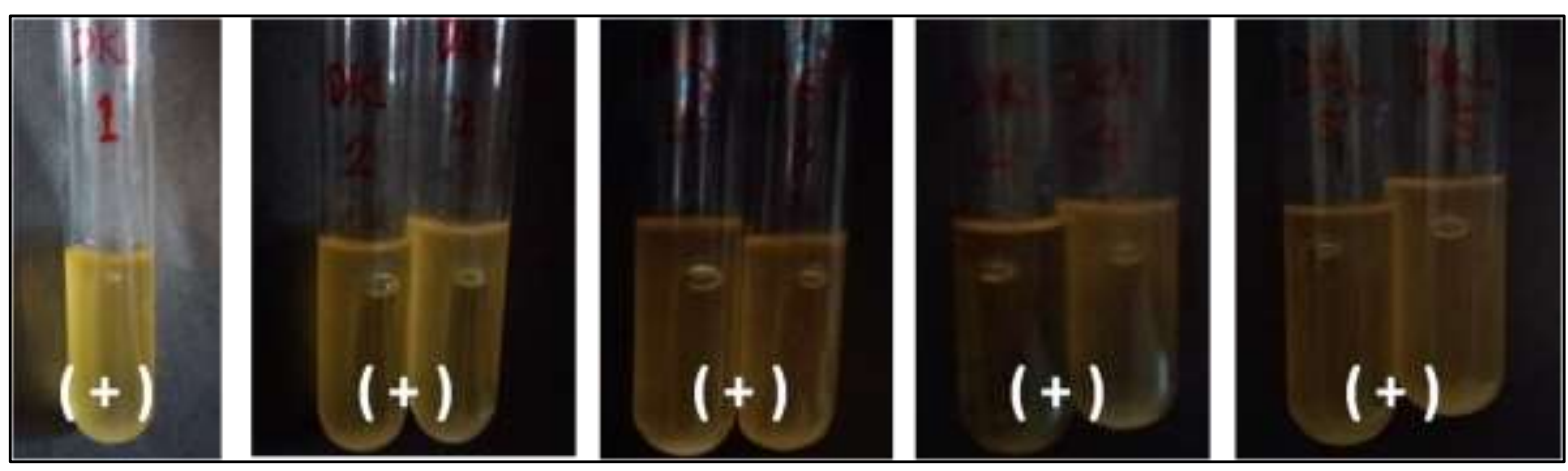

Gambar 3. Hasil uji biokimiawi melalui fermentasi laktosa bakteri isolat DKL1-5 (dari kiri ke kanan): (+) terbentuk gas dalam tabung durham

Tabel 2. Morfologi sel koloni bakteri isolat terpilih berdasarkan pengecatan Gram

$\begin{array}{lllll}\text { Isolat Terpilih } & \text { Morfologi Sel } & \text { Sifat Gram } & \text { Bentuk S } \\ \text { DKL 1 } & & \text { Negatif } & \text { coccus } \\ & & & \\ & & & \end{array}$




\section{DKL 2}

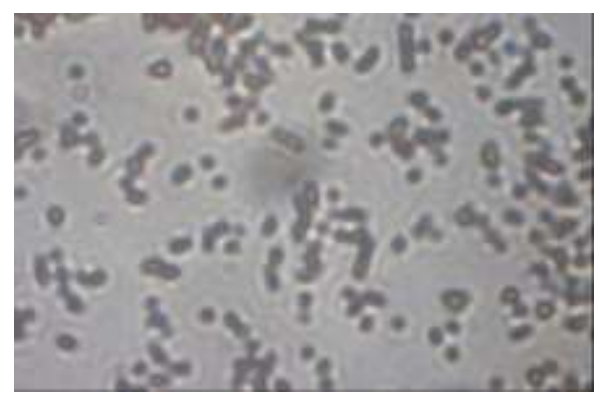

DKL 3

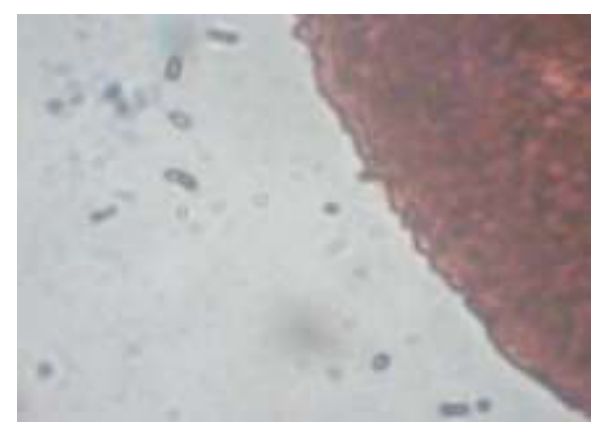

Negatif

coccus

DKL 4

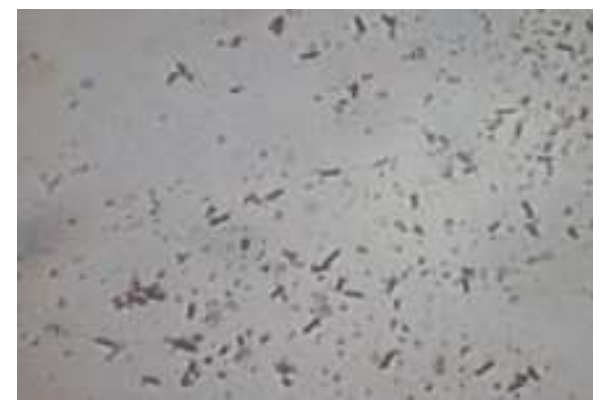

Negatif

Bacil

DKL 5

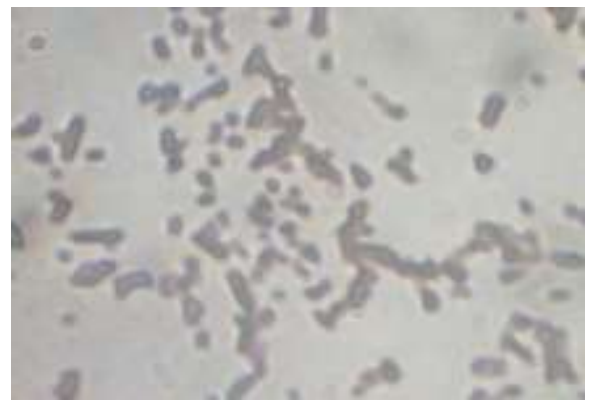

Negatif

coccus

Ket: Pengamatan di bawah mikroskop dengan perbesaran 1000x

\section{UCAPAN TERIMA KASIH}

Penelitian ini didanai oleh Program Penelitian Insentif Dosen Pemula FMIPA Universitas Tadulako (Surat Keputusan Dekan No. 3192/UN28.1.28/KP/2016). Penulis mengucapkan terima kasih yang sebesar-besarnya kepada pihak Balai Besar
Taman Nasional Lore Lindu Sulawesi Tengah atas kemudahan dalam pengambilan sampel penelitian. Ucapan terima kasih juga disampaikan kepada seluruh pihak yang telah membantu selama proses penelitian hingga penerbitan artikel ini. 


\section{DAFTAR PUSTAKA}

Aanniz, T., Ouadghiri, M., Melloul, M., Swings, J., Elfahime, E., Ibijbijen, J., Ismaili, M., and Amar, M., 2015, Thermophilic Bacteria in Moroccan Hot Springs, Salt Marshes and Desert Soils, Braz. J. Microbiol., 46: 443-53.

Balai Besar Taman Nasional Lore Lindu, 2015, SK Zonasi TNLL Kab Sigi \& Poso,

(http://www.lorelindu.info/index.php/ peraturan-perundangan/sk-zonasitnll), diakses tanggal 26 Desember 2016.

Cappuccino, J. G., and Sherman, N., 2008, Microbiology: A Laboratory Manual, Pearson, New York.

Dwijoseputro, D., 2005, Dasar-Dasar Mikrobiologi, Djambatan, Jakarta.

Glick, B. R., 1995, The Enhancement Of Plant Growht By Free-Living Bacteria, Can. J. Microbial., 4: 109117.

Joetono, Judoro, S., Hartadi, S., Kabirun, S., Suhadi, D., dan Soesanto, 1980, Pedoman Praktikum Mikrobiologi untuk Perguruan Tinggi, Departemen Mikrobiologi Fakultas Pertanian, Yogyakarta.

Kloepper, J. W., Mahaffee, J. A., Mcinroy, and Bacman, P. A., 1991, Comparative Analysis of Isolation Methode for Recovering RootColonizing Bacteria from Roots, In Keel, C., Koller, B., and Defagos, G. (Eds.), pp.252-255.

Kloepper, J. W., 1993, Plant Growth Promoting Rizobakteria as Biological Control Agent. In Meeting, F. B. Jr. (Ed), Soil Mikrobial Ecology, Application in Agricultural and Environental Management, Marcel Dekker, New York, pp. 255-274.

Lambui, O., Sembiring, L., dan Rahayu, E. S., 2015, Potensi Isolat Bakteri Asam Laktat dari Bunga Tigarun (Crataeva nurvala Buch. Ham.) Sebagai Penghasil $\beta$-Galaktosidase, Prosiding Seminar Nasional Biologi Jurusan
Biologi FMIPA Universitas Tadulako, Palu, Sulawesi Tengah, 28 September 2015, pp: 70-78

Lay, B., 1994, Analisis Mikroba di Laboratorium, Grafindo Persada, Jakarta.

McNeil, B., and Harvey, L., 2008, Practical Fermentation Technology, John Wiley and Sons Ltd., England.

Pelczar, M. J., and Chan, E. C. S., 1986, Dasar-Dasar Mikrobiologi Jilid 1, Alih Bahasa oleh Hadieotomo, R. S., Imas, T., Tjitrosomo, S. S., and Angka, S. L., UI Press, Jakarta.

Pitopang, R., 2006, Structure and Composition of Six Land Use Types Different in Use Intensity in the Lore Lindu National Park, Central Sulawesi, Indonesia [Dissertation], Post Graduate Program Bogor Agricultural University, Bogor.

Rahayu, E. S., dan Margino, S., 1997, Bakteri Asam Laktat: Isolasi dan Identifikasi. Materi Workshop PAU Pangan dan Gizi Universitas Gadjah Mada, Yogyakarta, 13-14 Juni 1997.

Saraswati, R., Husen, E., dan Simanungkalit, R. D. M., 2007, Pengambilan Contoh Tanah untuk Analisis Mikroba, Dalam: Metode Analis Biologi Tanah, Balai Besar Penelitian dan Pengembangan Sumberdaya Lahan Pertanian, Bogor. Simanungkalit, R. D. M., 2006, Pupuk Organik dan Pupuk Hayati : 6. Bakteri Penambat Nitrogen, Balai Besar Litbang Sumberdaya Lahan Pertanian Badan Penelitian dan Pengembangan Pertanian, Bogor.

Sneath, P. H. A., Mair, N. S., Sharpe, M. E., and Holt, J. G. (eds), 1986, Bergey's Manual of Systematic Bacteriology Volume 2, Williams and Wilkins, Baltimore.

The Nature Conservancy, 2001, Community Consultations Provide Key to Lore Lindu Success, The Nature Conservancy and Wahana Lingkungan Hidup (Walhi), Jakarta. 
Trimulyono, G., 2010, Bakteri Asam Laktat Penghasil Antimikrobia pada Tanaman Sayur [Tesis], Program Studi Biologi Program Pascasarjana Fakultas Biologi Universitas Gadjah Mada, Yogyakarta. 